\title{
TV/Series
}

15 | 2019

La Sérialité en question(s)

\section{How to study the complexity of television series? Towards a spatial approach}

\section{Mireille Berton and Marta Boni}

Translator. Laura Haydon

\section{OpenEdition \\ Journals}

\section{Electronic version}

URL: http://journals.openedition.org/tvseries/4991

DOI: 10.4000/tvseries.4991

ISSN: 2266-0909

\section{Publisher}

GRIC - Groupe de recherche Identités et Cultures

\section{Electronic reference}

Mireille Berton and Marta Boni, "How to study the complexity of television series? Towards a spatial approach ", TV/Series [Online], 15 | 2019, Online since 16 March 2021, connection on 21 March 2021 URL: http://journals.openedition.org/tvseries/4991 ; DOI: https://doi.org/10.4000/tvseries.4991

This text was automatically generated on 21 March 2021.

\section{cc)}

$T V /$ Series est mis à disposition selon les termes de la licence Creative Commons Attribution - Pas d'Utilisation Commerciale - Pas de Modification 4.0 International. 


\title{
How to study the complexity of television series? Towards a spatial approach
}

\author{
Mireille Berton and Marta Boni \\ Translation : Laura Haydon
}

1 How do we study the specificities of series, these evolving, multi-sided, open, fragmented stories? Today, not only are series broadcast and disseminated via different media, they are also consumed in a variety of ways, as illustrated by the Marvel franchises, whose release of several films with connected plots was combined with television series broadcast on generalist networks or on Netflix. In the context of extended serialization, the repetition and necessary variation, typical of seriality ${ }^{1}$, continues to attract, gain the loyalty of, and surprise consumers (who are, in turn, content producers). Thus, should we not view seriality as a transversal phenomenon which is part of the cultural history of different media ${ }^{2}$ - transmedia worlds ${ }^{3}$ being universes or systems of content from which a repertoire of stories and fictional characters can be actualized through several media?

On the basis on this observation, we can highlight three problems which emerge for researchers who try to describe them:

1. the problem of quantity (in the context of an excess of data, an "over-supply situation", to borrow a phrase from Yves Citton $\left.^{4}\right)$;

2. the problem of instability (forms and platforms are constantly rearranging themselves);

3. the problem of complexity (the series is a non-discrete, or continuous, object whish transforms in time according to a progression which, in some cases, is planned by the producers, but which also deserves to be thought of in the framework of porous frontiers between the different reception domains).

The question of the legitimacy of television series dominated early work which systematically reserved the right to focus on popular culture ${ }^{5}$. This work aimed to show that TV series merit a place in the pantheon of works of "art" (think about the place of honour they occupy at film festivals like Cannes or Sundance or at festivals specifically 
dedicated to the genre, like Series Mania in Lille). Yet, if this question is no longer topical, other questions appear around the manner of analysing these objects and their proliferation. Must we rely on tools from other disciplines which traditionally explore artistic production, such as literature or film studies, or is it necessary to draw up new ones? How should we apprehend extremely dense and reflexive objects which not only seem to deal with the critical discourse which is normally the preserve of analysts, critics, historians, but which is also fed by the discourse of fans and the varied appropriations which populate the web? In this context, are the tools of film or literary studies sufficient, or do we need to design methods better able to give an account of the multi-sided nature of serial fiction?

In their "Préface. Les séries télé dans le monde. Échanges, déplacements et transpositions", Sylvaine Bataillet and Sarah Hatchuel discuss the relevance of inventing a discipline entitled "television series studies" - a question which they respond to in the negative: "to create a new, independent discipline would, in our eyes, be to forgo insights, methodologies, approaches that are specific to a range of disciplines capable of producing original, rich, varied and evolving research ${ }^{6}$." As a subject, "television series" can, in effect, be defined as a form of serialised story, a commercial product, a work of art, entertainment, a thought experiment, a cultural practice. Thus the need to deploy different types of resources, drawn from a range of disciplines, as illustrated in the work done in sociology, information and communication sciences, cultural studies, political economics, postclassical narratology, neuroscience, psychoanalysis, philosophy, etc. Studies undertaken in France by Séverine Barthes ${ }^{7}$ and Barbara Laborde ${ }^{8}$ brings to light the very broad range of methods used - Laborde underlining the recurrence of work which cuts across standpoints and analytical tools, but also the lack of consensus and the difficulty of combining the different disciplines which address the subject.

Adopting this interdisciplinary approach, we will develop a discussion which aims to understand how several disciplines which seem disparate at first glance, such as geography and film studies, or literary studies and digital humanities, can help us to study series. More broadly, we aim to contribute a reflection on the place that the study of this subject could occupy in humanities and social sciences, keeping in mind the need to crosscut existing approaches as well as invent new ones in order to adapt to the incessant mutations of the field of reference drawn by television series.

First of all, we will tackle the linked problems of the quantity, instability and complexity posed by TV series and secondly, suggest an approach which will enable us to grasp this complex subject, in order to discuss the contribution of the digital humanities.

\section{The problem of quantity}

7 Studying TV series is always something of a challenge because of the heterogeneity of the corpus, the multiplicity of components and their spread in the media sphere. "Television series" is a difficult subject to study because of the variety and scale of the corpuses which can be hundreds of hours long. Thus, the first observation concerns the quantity of audio-visual objects, which proliferate endlessly. How can we actually apprehend these programmes in the era of "Peak TV", a term coined in August 2015 by John Landgraf, director the American TV channel FX, to highlight the cornucopia that 
the plethora of TV channels were offering? From 2009 to 2017, the number of series broadcast in the US went from around 200 to almost 490, not including international productions ${ }^{9}$. The proliferation of social players involved in the production is partly responsible for this "peak" in production, and the sign of creative emulation but also a source of growing pressure on television industry bosses who must remain competitive. Many journalists have pointed out the consequences of this abundance for users: it ends up generating as much anxiety as pleasure, with fans living in fear of missing out on the perfect series and not being able to join in conversations about the latest hot trend. On the research front, we are immediately faced with the difficulty of apprehending such large corpuses cogently, unless we do it by limiting the material and focussing on case studies which yield more information and nuances, and potentially map out the trends governing different analogue series.

\section{The problem of instability}

The second challenge we face when studying television series resides in the constant mutation - and therefore instability - of television's forms and platforms, a medium which has never had a fixed identity ${ }^{10}$, not to mention the absence of stable criteria to define this multiplicity, especially in a transnational context. This challenge arises because the TV series can be defined in different ways, according to one's point of view, but also according to which cluster is selected as a prism, be it production, broadcasting, reception or consumption. In the French-speaking world, several terms have been coined to categorise series relative to their temporal organization ${ }^{11}$, which rarely correspond to typologies constructed in other countries ${ }^{12}$. This plurality of reading grids is evidence of a lack of consensus on forms, formats (the term is itself used to define, on the one hand, the immutable "recipe" for transnational imports by Moran and Chalaby and others, and on the other hand, the relationship with time and form by Soulez ${ }^{13}$ ) and the series' "formulas". It also emphasizes that the main focus for researchers is the relationship with time, considered critical to grasping the variability and richness of these objects. Florent Favard's brilliant analysis of the fascination with the "teleological" series ${ }^{14}$ underpins this focus on the temporal dimension of series.

9 Studying television series demands that we be highly responsive to the transformations of the cultural industries which are constantly adapting their editorial policies to the dictates of the market and the public. For example, in response to the phenomenon of "Peak TV" and its saturating effects, in recent years TV channels have tended to reduce the number of new series, offering shorter series in terms of seasons and episodes (whose duration can fluctuate), favouring mini-series or anthology series, and avoiding rushing to cancel a production on the basis of unsatisfactory viewing figures (because it might still be viewed after the end of the scheduled broadcast on other platforms and in other formats). Another strategy consists of eking out successful series for as long as possible by inserting longer breaks between seasons, as with Game of Thrones (HBO, 2011-2019) or Westworld (HBO, 2016-).

10 Luca Barra's work ${ }^{15}$ on the American comedy genre confirmed these transformations. The genre's narrative strategies and strategies for viewer involvement have been progressively modified following the appearance of new modes of broadcasting and consumption sparked by on-demand video platforms and streaming. While 1990s comedies sought to involve the viewer through laughter and the broadcasting of 
episodes to match the rhythms of daily life (the series closely following the social calendar), new comedies like Master of None (Netflix, 2015-) or Atlanta (FX, 2016-) partially jettison laughter in favour of the codes of drama and melodrama (they become "dramedies"), and consist, in their early seasons, of relatively self-contained episodes dealing with a specific topic (often referenced in the title). According to Barra, the practice of viewing on non-televisual devices has thrown the principle of synchronising with the daily life of users into crisis, with writers and producers having to find ways of retaining viewers, while also supporting new consumption practices like "bingewatching". The connection with the public therefore depends on a reduction of the principle of repetition (central to the comedy genre), a simplification of plotlines, a weakening of the chronological alignment with social rhythms, and an assimilation of the codes of drama and melodrama which favour attachment to a fictional universe ${ }^{16}$.

\section{The problem of (chiefly) narrative complexity}

11 Beyond the quantity and instability of production and their respective consequences for reception, arises the problem of the narrative and aesthetic excellence of certain series where everything is totally deconstructed and self-conscious: stereotypes are present but they are questioned; all points of view are represented and incarnated by different characters who are all complex and contradictory; all interpretations are possible, including those which are incompatible with each other. It can therefore be difficult to embark on a process of deconstruction because this deconstruction is included in the series themselves. Current fictional series manifest a very high degree of reflexivity which makes them both complete and complex objects, integrating their own interpretation, indeed their own critique, into the diegesis, rhetoric and textual functioning. This metadiscursive dimension can risk making us prisoners of our own admiration, the "perfection" of these objects being liable to partially inhibit critical thinking.

Jason Mittell suggests a conceptual framework to distinguish between different types of serialising stories within a paradigm that he calls "Complex TV". The latter (not to be confused with "QualityTV17") refers to series which variously combine episodic and soap opera logic and which fully involve the viewer by encouraging concentration and participation through storylines that are aesthetically as well as narratively rich. This term applies in particular to drama series like The Wire (HBO, 2002-2008), Lost (ABC, 2004-2010), Mad Men (AMC, 2007-2015), Breaking Bad (AMC, 2008-2013), Game of Thrones, House of Cards (Netflix, 2013-2018) or True Detective (HBO, 2014-), which are deemed sophisticated and nuanced, revealing a complex world vision which is enriched through successive episodes and seasons. This type of complexity is characterised by stories with a highly articulated logic and temporality which is often non-linear, like "puzzle films s" 18 " "multi-draft narratives ${ }^{19}$ ". In these cases, the concept of "Complex TV" serves to define an object and the challenges it represents for viewers, emphasizing the hermeneutic circle whose parts must be constantly in relationship with the whole ${ }^{20}$. Also, the numerous studies addressing the question of the narrative complexity of TV series regularly considers them through the prism of a complex arrangement of elements along a temporal axis, with the dialectic between innovation and repetition as its basic unit ${ }^{21}$. 

"Complex TV" which rests on a rationale of long-term interconnections between the episodes $^{22}$, engaging viewers in a paperchase or a "mind-game" highly favourable to narrative tension and the suspenseful wait for a climax which is forever postponed ${ }^{23}$. Often compared in the media to Stranger Things (Netflix, 2016-), mainly because of its chronotope (a little village in the 1980s), this series which has now completed two seasons tells the story of a series of disappearances through the motif of time travel. In the shadow of the cooling towers of a nuclear power station, three eras converge (2009, 1986 and 1953) and a characters who proliferate in a worldly sense ${ }^{24}$, in order to populate these different temporal strata. To get one's bearings in this extremely indistinct narration, the viewer will find it helpful to use a family tree (freely available on the Net) to visualise the links formed by four families over three generations. This series, which is often compared with a puzzle or a maze (which is also diegetised), and based on a range of philosophical references (Plato, Goethe, Nietzsche, Schopenhauer), postulates a type of viewer willing to invest cognitively and intellectually in a demanding storyline, carried by a chiaroscuro aesthetic, which develops in a heavy atmosphere. As the many time-maps of the series and even the famous collaborative encyclopedia Lostpedia described by Mittell (2015) show, series like Lost had already taken their viewers a long way in developing hypotheses which could solve the mystery of the island where the survivors of a plane crash are trying to stay alive. But while in Lost the narrative complexities and the multiple flash-backs sometimes reflect a lack of inspiration on the part of the scriptwriters, who don't know how to complete certain story $\operatorname{arcs}^{25}$, in Dark, this tangle of spatio-temporal layers is very finely constructed so as to catch those viewers destined to become "hyper-cognitive ${ }^{26}$ " viewers. terms. Think, for example, about campaigns by fans to save a series which is due to be cancelled, like Sense8 (Netflix, 2015-2018) in 2017. If they are augmented storylines comparable to "narrative ecosystems ${ }^{27}$ ", they extend their frontiers beyond their textual limits because they persist through different offshoots, thus forming a "world" which takes precedence over the plot itself ${ }^{28}$; they persist on social networks, blogs, forums, fan sites, where they give rise to readings and commentaries which enrich the original story - phenomena which can be analysed in light of the concept of transfictionality ${ }^{29}$. Thus, the challenge of complexity also applies to the position the series occupies in the media sphere, including transmedia footprints and the discursive practices generated by users.

\section{TV series and the spatial approach}

The analysis of the "television series" object cannot, therefore, avoid extending its frontiers, both in terms of quantity and complexity. But which approaches and tools should be used? Without doubt, it requires us to take account of certain parameters which are specific to the subject, such as the principle of the serial story prone to infinite development ${ }^{30}$, or even the economic dimension of a "work of art" which also a commercial product ${ }^{31}$. We should add to that the spatial dimension of the television series, which is present in the diagesis and in the interactions between users, the fictional universe and the production sphere ${ }^{32}$. 
16 As Letourneux reminds us, the analysis of serialised stories - which have a dominant place in our culture and in our daily lives - requires that we forge original modes of interpretation because this type of fiction renders notions of authorship, 'works of art' and artistic legitimacy obsolete ${ }^{33}$. It is for this reason that we must avoid "apprehending these products via analytical frameworks of received culture, seeking to showcase the genre's great authors, original serial works, specific visions of the world. $[. . .]^{34 "}$. Letourneux encourages us to rethink seriality in a way which jettisons the prevailing analytical models. For us, it's about finding an alternative to analytical work which tends to focus on the temporal progression of a serial story, mainly addressing the issue of the number of episodes and seasons in terms of narrative organization, as does Jean-Pierre Esquenazi, who understands the television series as a temporal art ${ }^{35}$. And yet, the series can also be grasped as a spatial art, the consumption of multiple fictions also being made up of interruptions (between episodes, between seasons, between a series and its resurrection), which are not merely temporal intervals justified by the narration, but also interstitial spaces, satellite territories which all serial writing must contend with - and which are, furthermore, enriched by viewer discourse and by other paratexts. This manner of grasping the series as a spatial art therefore encourages us to consider the series as a complement to the temporal perspective, in its spatial dimension and organisation.

17 Serial stories are also a lot more than the expression of an industrialized popular culture which produces standardised fiction, because this point of view tends to overlook "the heterogeneity of practices, authorial positions and meanings that the texts can take on once invested by various social groups ${ }^{36 "}$. The analysis of serial productions ought ideally to encompass the analysis of the production context (which Letourneux calls "architextual dynamics" extrapolating Genette's notion which originally barely acknowledged contextual elements) and textual analysis (the microanalysis of style, narrative, aesthetics, semantics, etc.). Indeed, it seems impossible to consider Game of Thrones without factoring in its integration into the architext created by HBO who heavily determine content, notably by codifying the series as "Quality TV" ${ }^{37}$. Besides, the television series can also be read in terms of transcendence ${ }^{38}$ because, like a database, it constitutes one of the incarnated, immanent possibilities of a wider, transmedia and subjacent world. Thus, the television series can be considered in terms of space, insofar as it suggests a wider space which contains and then exceeds it, revealing a portion of this data set.

The evidence has shown how important it was to move beyond the sphere of the intertext to ascertain the economic context in which such a series appears, as well as the social milieu and its effects on viewers. Because as a mode of communication which relies on a "contradictory dynamic" (namely, the famous tension between reprise and variation), the serial story forces us to renew our analytical methods by taking into consideration a set of parameters, starting with "the collective and social dimension of discourse produced by serial works, which makes it one of the spaces where the ideological positions of an era can be expressed, along with the tensions that moderate public space ${ }^{39}$ ". As places of "ideological, social and aesthetic clashes ${ }^{40}$ ", series therefore require a combination of textual analysis and historical, media, social, economic and political issues. Let's not forget Jean-Pierre Esquenazi's appeal that we consider a work "not as an object, but as a historical process engendered in a social setting which is distinctive and capable of taking up residence in different settings and 
situations ${ }^{41}$ ". For these reasons, factoring in fans' appropriation practices and, more broadly, discursive practices, proves to be essential. If the text is, etymologically speaking, a network, the study of the media which propagate it in time and space must be tied to the analysis of its internal complexity.

This is why, based on Edgar Morin's thinking ${ }^{42}$, we propose using the model of the complex system so as to displace the focus away from the textual object (certainly complex from a narrative point of view) and towards the study of the interactions between the latter and its production and reception contexts. The focus will be on processing the footprints left by viewers of television series, namely, the artefacts which compose and accompany the viewing experience of any audio-visual product and which, fundamentally for a serial story, fill the spaces which separate the broadcast of each episode, each season, each series. The complex system encompasses and organises the material and becomes the terrain from which new practices and new meanings, as well as new narrative orientations, can arise: it's a model which offers solutions to the aporia which appears when we wish to analyse the space between the texts and the viewers.

The viewers are, in effect, generators of footprints resulting from a range of practices (narrative and non-narrative) which add themselves to the heterogeneous fabric of a complex story. The latter generally consolidates its identity through sharing on social networks. If the fragmentation and multiplicity of the data strongly determine the broadcasting of television series, there are nonetheless answers to be sought in terms of continuity because each element relative to a serial story resides in a system in continual expansion. Therefore, we propose to describe the series as a semiosphere ${ }^{43}$, or a semiotic space with a long-term memory and this not only in its substructures, but also as a characteristic of a complex system. The system is complex because each element cannot be thought of outside its link to the other elements in the system or the broader discursive space which contains it. In semiotic terms, the various media fragments find a form of unity or identity in the semiosphere which they make up, which also constitutes the condition of their existence. Therefore, the series is a "simultaneously unequal and yet unified, asymmetrical and yet uniform ${ }^{44 "}$ object. This conception of the television series as a complex semiotic system within which the footprints of a multitude of discourses converge encourages us to adopt a spatial methodology of the series, by using the tools offered up by the digital humanities and using the principle of multiplicity in our favour.

\section{The contribution of the digital humanities}

21 The series is a collection of data which can be harvested, compared and analysed at several levels. Projects born at the crossroads of television studies and digital humanities use the quantification of the duration of shots, or facial recognition algorithms to analyse the repetition and variation of forms within a series (for example Jeremy Butler's "Shot Logger" project) ${ }^{45}$. Furthermore, some American researchers (including, interestingly, Jason Mittell) have recently proposed turning to deformative criticism $^{46}$, namely a way of visualising the series as a collection of shots that a piece of software superposes, or looks for, via algorithms, with responses focussing on its form rather than its narrative dimension. If time remains a key concept (duration being a central category in this work), the current tendency is more about seeking paths which 
lead away from studies based on narratology or the analysis of performances. The series is defined using all the information it contains and is still more often apprehended as an agglomeration of data.

Following the imported model of semiotics of culture and the relationship of the series to the space, other methodological solutions involving the descriptions and metadiscourses surrounding the series, can be envisaged. An example would be turning to geography and taking as a research subject the TV series as it appears in real geographical space. Research undertaken by the Labo Télée ${ }^{47}$ searches for series titles in the Internet Movie Database (IMDb) and situates them on a map in order to piece together a cartography of the global series panorama (as listed in the IMDb, so certainly subject to Western hegemonic biases) which will allow us to formulate questions about the number of episodes, the professionals involved, series genres, all in terms of localisation in real space. Observations about the recurrence of film locations or producing or importing countries are therefore possible using an interactive map which is also a search engine. This approach, which is based on the spatialisation of the analysis of formal and industrial categories, inspired the work of Franco Moretti in literature studies: in his case, a "distant reading" of very broad corpuses sees the emergence of variations in the forms and modes of production, without any of the traditional "close reading" which Moretti associates with biases of subjectivity and cultural legitimacy ${ }^{48}$.

Choosing distance as a reading method means researchers can espouse a point of view that is respectful of slower, microscopic historical transformations and, beyond that, restore a "Darwinian" vision of the corpus's structural mutations. Researchers with the Narrative Ecosystems ${ }^{49}$ group offer an example of this practice. However, if Moretti's position remains marked by a certain structuralist positivism, the maps can reveal much more than the geopolitical relationships which depend on official discourse because, in accordance with the image of the semiosphere described above, they also offer information about the existence of alternative discourses anchored in the daily lives of users.

In that regard, we have shown, through an analysis of the way Twin Peaks. The Return (Showtime, 2017) was received on Twitter and other social networks, that using maps as a tool can inform several aspects of the life of a series, understood in spatial and semiospheric terms ${ }^{50}$. Using open access software like OneMillionTweetMap, has, for example, allowed the localisation of fan discourse to become visible: instead of measuring the amount of content shared by fans or tweets containing the selected hashtag in purely statistical terms, thanks to the maps, we have been able to see the intensity with which a series can occupy a certain space in global geographic space. The intensity is determined by a greater density of discourse footprints in a particular place or at a given moment, for example the first and last episodes in a season, and informs us about the synchrony of the reception and uses - this is all the more interesting as it happens despite the fact that Post Network television means the viewer can choose where and when to watch. These visualisations can also become springboards for an analysis of piracy or circumventing geo-blocking devices ${ }^{51}$. Thus, the series becomes a cultural forum because if this term used to refer to generalist television on a nationwide scale, in this era of digital platforms it could equally apply to lots of niches in the public space. Potentially, each of these footprints could encourage new forms of consumption, functioning like a doorway to the world of the series. 

participation correspond to the beating heart in the body of the series: that is where "something's happening" and it's here that the new questions can arise - taking care, nonetheless, not to surrender to a form of determinism or predictive will. Series are also places of interference, thrown up by the encounter - and therefore the necessary adaptative reaction - with extra-textual material (other series, other media), as with trans-fictional phenomena. The serial space is thus composed of microscopic situations and macroscopic structures: forms emerge from very slow mutations, struggles and frictions, but also from convergences within the global media panorama and within these semiospheres that series constitute - living organisms in which unexpected associations between different parties are possible. disciplines, we can describe the implications of an approach based on interferences between forms and platforms, between the sphere of the official text and the sphere of its reception, with the aim of finding answers or elements of answers to questions about the uses, aesthetics and narration of series. On the one hand, the chosen model necessarily contends with questions asked previously; on the other hand, unforeseen occurrences or results can arise. The analysis is in fact based on reception footprints from key words chosen on the basis of a prior knowledge of online modes of discursivity, as well as on a series of hypotheses about the series and a deep knowledge of its production and broadcasting context. With Twin Peaks, it meant seeking answers about its cult status, already confirmed by a number of studies of the work and its reception. But beyond that, and considering these premises, the proposed model encourages us to abandon an analysis based on discreteness (the series as an object whose boundaries are drawn in advance by textual constraints imposed by the official producers) and, rather, to think of the series as a continuous space, in which a number of heterogeneous elements cross and overlap. Fresh questions can now arise in the space situated between the texts and the viewers.

\section{Conclusion}

The series is therefore analysable at its spatial level, and from a certain distance, due to its proliferation across a number of territories and the ability to access the interpretative footprints which endlessly overlap, this data then allowing us to visualise its quantitative, formal and technological dimensions. The spatial approach is prone to define the serial object in its narrative and non-narrative complexity, and ultimately fosters a phenomenon which traverses and saturates the whole of the current media panorama: if Umberto Eco considered the dialectic between repetition and innovation as being central to serial temporality (and more broadly to postmodern aesthetics), thinking of the television series in terms of space allows us to apprehend it through principles of both the constant availability of transmedia elements, and the multiple auctoriality of which it is made up, like a database - an instrument (and metaphor) intrinsic to our digital age. It is therefore time to find and to experiment with new tools and conceptual models which would be capable of characterising television seriality in its temporal and spatial coordinates, and to help us, as Carrie Mathison did when she meticulously carpeted the wall of her apartment with post-its 
in Homeland (Showtime, 2011-), to see more clearly the links and the knots of a complex system, through its spatial organisation.

\section{BIBLIOGRAPHY}

ALLEN, Robert C. (dir.), To Be Continued... Soap Operas Around the World, Londres, New York, Routledge, 1995.

BARONI, Raphaël, La Tension narrative. Suspense, curiosité, surprise, Paris, Seuil, 2007.

BARONI, Raphaël, Jost François (dir.), « Repenser le récit avec les séries télévisées », Télévision, $\mathrm{n}^{\circ}$ 7, 2016 : https://www.cairn.info/revue-television-2016-1.htm, consulted on 7 July 2019.

BARRA, Luca, "Master of None, Atlanta, and Audience Engagement in Contemporary American TV Comedy", 16:9. Filmtidsskrift, 19 Novembre 2017 : http://www.16-9.dk/2017/11/master-of-none/, consulted on 7 July 2019.

BARRA, Luca, « Les formes, durées et formats des comédies télévisuelles américaines. Distribution, engagement du public et instabilité des frontières de genre », in BONI, Marta (dir.), Formes et plateformes de la télévision à l'ère du numérique, Rennes, Presses Universitaires de Rennes, 2019.

BARTHES, Séverine, « Panorama de la recherche universitaire sur les séries télévisées en France ", Premières Rencontres des Séries Télévisées, France, 2004 : http://hal.archives-ouvertes.fr/ hal-00470237 (consulté le 7 juillet 2019).

BATAILLE, Sylvaine, HATCHUEL Sarah, « Préface. Les séries télévisées dans le monde : échanges, déplacements et transpositions », TV/Series, $n^{\circ} 2,2012$, placed online on 1 November 2012 : http:// journals.openedition.org/tvseries/1351, consulted on 7 July 2019.

BENASSI, Stéphane, Séries et feuilletons T.V. : pour une typologie des fictions télévisuelles, Liège, Éditions du CEFAL, 2000.

BENASSI, Stéphane, «Transfictions », MédiaMorphoses, Hors-Série, « Les raisons d'aimer les séries télé », Paris, Armand Colin, 2007, p. 158-162.

BERTON, Mireille, « Flashback, trauma et répétition narrative dans les séries américaines contemporaines », Télévision, $\mathrm{n}^{\circ}$ 7, 2016, p. 173-189.

BESSON, Anne, Constellations. Des mondes fictionnels dans l'imaginaire contemporain, Paris, CNRS Édition, 2015.

BESSON, Anne, « De l'ensemble à la totalité : l'effet de monde dans les littératures de l'imaginaire contemporaines », Belphégor, n 14, 2016 : http://journals.openedition.org/belphegor/650, consulted on 7 July 2019.

DOI : 10.4000/belphegor.650

BOILLAT, Alain, Cinéma, machine à mondes : essai sur les films à univers multiples, Genève, Georg, 2014. 
BONI, Marta, Romanzo Criminale. Transmedia and Beyond, Venise, Ca' Foscari Online Publishing, 2013, http://virgo.unive.it/ecf-workflow/upload_pdf/Innesti_2.pdf.

BONI, Marta, « Mondes sériels et complexité », Écrans, 2015, Volume 2, n 4, p. 55-68.

BONI, Marta, “Working with Maps: Systems, Networks, Series”, in CAVALLOTTI, Diego, GIORDANO Federico, QUARESIMA, Leonardo (dir.), A History of Cinema Without Names II. A Research Project, FilmForum/2015, Udine, Mimesis, 2017, p. 69-76.

BONI, Marta (dir.), World Building. Transmedia, Fans, Industries, Amsterdam, Amsterdam University Press, 2017.

DOI : $10.1515 / 9789048525317$

BONI, Marta, « Des téléspectateurs géolocalisés ». Sens Public, 15 December 2017 : http:// www.sens-public.org/article1283.html, consulted on 7 July 2019.

DOI : $10.7202 / 1048867$ ar

BORDWELL, David, "What-if Movies: Forking Paths in the Drawing Room", Observations on film art (blog), 2014: http://www.davidbordwell.net/blog/2014/11/23/what-if-movies-forking-pathsin-the-drawing-room/, consulted on 7 July 2019.

BUCKLAND, Warren (dir.), Puzzle Films: Complex Storytelling in Contemporary World Cinema, Malden, Wiley-Blackwell, 2009.

BUONANNO, Milly, Le formule del racconto televisivo. La sovversione del tempo nelle narrative seriali, Florence, Sansoni, 2002.

BUXTON, David, Les séries télévisées. Formes, idéologie et mode de production, Paris, L'Harmattan, 2010.

CARDINI, Daniela, "Serial Contradictions: The Italian Debate on TV Series", Series. International Journal of TV Serial Narratives, Volume II, n 1, spring 2016, p. 47-54: https://series.unibo.it/ article/view/6163, consulted on 7 July 2019.

CARDINI, Daniela, « Il tele-cinefilo. Il nuovo spettatore della Grande Serialità televisiva ", Between. Rivista dell'Associazione di Teoria e Storia Comparata della Letteratura, Volume 4, $\mathrm{n}^{\circ}$ 8, November 2014, p. 1-30 : http://ojs.unica.it/index.php/between/article/view/1361? fbclid =IwAR01riiC45RrKUXLIl4lT_Gv0YlPmPclEneLMrMEa1mbG8CmOkh_QkrQ9jY, consulted on 7 July 2019.

CAUGHIE, John, "Telephilia and Distraction: Terms of Engagement", Journal of British Cinema and Television, Volume 3, $\mathrm{n}^{\circ}$ 1, January 2008, p. 5-18.

DOI : 10.3366/JBCTV.2006.3.1.5

CITTON, Yves, Pour une écologie de l'attention, Paris, Seuil, coll. « La Couleur des idées », 2014.

CHALABY, Jean, The Format Age: Television's Entertainment Revolution, Cambridge, Polity, 2015.

COLONNA, Vincent, L'art des séries télé, Paris, Payot, 2015.

DE KOSNIK, Abigail, « Piracy is the Future of Television », Convergence Culture Consortium, 2018, http://convergenceculture.org/research/c3-piracy_future_televisionfull.pdf, consulted on 7 July 2019.

ECO, Umberto, « Innovation et répétition : entre esthétique moderne et post-moderne », Réseaux, $n^{\circ} 68,1994$, p. 1-18.

DOI : $10.3406 /$ reso.1994.2617

ESQUENAZI, Jean-Pierre, Les séries télévisées : l'avenir du cinéma ?, Paris, Armand Colin, 2007a. 
ESQUENAZI, Jean-Pierre, Sociologie des œuvres : de la production à l'interprétation, Paris, Armand Colin, 2007b.

ESQUENAZI, Jean-Pierre, Éléments pour l'analyse des séries télévisées, Paris, L'Harmattan, 2017.

FAVARD, Florent, La promesse d'un dénouement. Énigmes, quêtes et voyages dans le temps dans les séries télévisées de science-fiction contemporaine, doctoral thesis, Université Bordeaux Montaigne, 2015.

FAVARD, Florent, Le récit dans les séries de Science-fiction de Star Trek à X-files, Paris, Armand Colin, 2018.

FEUER, Jane, "HBO and the Concept of Quality TV”, in Janet MacCabe and Kim Akass (dir.), Quality TV: Contemporary American Television and Beyond, London, I.B. Tauris, 2007, p. 145-157.

GLEVAREC, Hervé, La sériephilie. Sociologie d'un attachement culturel, Paris, Ellipses, 2012.

GOUDMAND, Anaïs, « Narratologie du récit sériel. Présentation de quelques enjeux méthodologiques ", Proteus [en ligne], n 6, 2013, p. 81-89 : http://www.revue-proteus.com/ abstracts/06-10.html, consulted 7 July 2019.

GOUDMAND, Anaïs, « Les séries transmédiatiques. Des univers sans fins ? ", Proteus, $\mathrm{n}^{\circ}$ 9, 2015, p. 8-18: http://www.revue-proteus.com/articles/Proteus09-1.pdf, consulted 7 July 2019.

HVEN, Steffen, Cinema and Narrative Complexity. Embodying the Fabula, Amsterdam, Amsterdam University Press, 2017.

DOI : $10.5117 / 9789462980778$

INNOCENTI, Veronica, PESCATORE, Guglielmo, "Changing Series: Narratives Models and the Role of the Viewer in Contemporary Television Seriality", Between. Rivista dell'Associazione di Teoria e Storia Comparata della Letteratura, Volume 4, n 8, 2014, p. 1-15 : http://ojs.unica.it/index.php/ between/article/view/4, consulted on 7 July 2019.

JENKINS, Henry, La culture de la convergence : des médias au transmédia, Paris, Armand Colin, 2013.

JENKINS, Henry, "Transmedia Education: the 7 Principles Revisited”, Confessions of an Acafan (blog): http://henryjenkins.org/blog/2010/06/transmedia_education_the_7_pri.html, consulted on 7 July 2019.

LABORDE, Barbara, “Television Series: Inventory of Research in France”, Series. International Journal of TV Serial Narratives, Volume III, n² 2, winter 2017 : https://series.unibo.it/article/view/ 7631, consulted on 7 July 2019.

LETOURNEUX, Matthieu, Fictions à la chaîne. Littératures sérielles et culture médiatique, Paris, Seuil, 2017.

LETOURNEUX, Matthieu (dir.), « Sérialités », Belphégor, n 14, 2016 : http://

journals.openedition.org/belphegor/647, consulted on 7 July 2019.

LOTMAN, Yuri, Universe of the Mind: A Semiotic Theory of Culture, Bloomington, Indiana University Press, 1990.

MICHLIN, Monica, "More, More, More. Contemporary American TV Series and the Attractions and Challenges of Serialization As Ongoing Narrative", Mise au point, $\mathrm{n}^{\circ} 3$, 2011: http:// map.revues.org/927, consulted on 7 July 2019.

MORETTI, Franco, Atlas of the European Novel, 1800-1900, London, Verso, 1999.

MORETTI, Franco, "Planet Hollywood”, New Left Review, n 9, May-June 2001 : https:// newleftreview.org/II/9/franco-moretti-planet-hollywood, consulted on 7 July 2019. 
MORETTI, Franco, Graphs, Maps, Trees: Abstract Models for a Literary History, London, Verso, 2005.

MITTELL, Jason, Complex TV: The Poetics of Contemporary Storytelling, New York, NYU Press, 2015.

MORAN, Albert, Copycat Television: Globalisation, Program Formats and Cultural Identity, Luton, Bedfordshire, UK, University of Luton Press, 1998.

MORIN, Edgar, Introduction à la pensée complexe, Paris, Seuil, 2005.

RE, Valentina, « Beyond the Threshold. Paratext, Transcendence, and Time in the Contemporary Media Landscape », in NOTO, Paolo, PESCE, Sara (dir.), The Politics of Ephemeral Digital Media: Permanence and Obsolescence in Paratexts, New York, London, Routledge, 2016, p. 60-74.

RODRIGUEZ, Ashley, “The End of Peak TV Must Finally, Mercifully Be Nigh”, Quartz, 13 January 2018: https://qz.com/999827/the-end-of-peak-tv-must-finally-mercifully-be-nigh/, consulted on 7 July 2019.

SAINT-GELAIS, Richard, Fictions transfuges. La transfictionnalité et ses enjeux, Paris, Seuil, 2011.

SOULEZ, Guillaume, KITSOPANIDOU, Kira (dir.), « Le levain des médias - Forme, format, média ». MEI - Médiation et information, n³9, Paris, L'Harmattan, 2015.

URICCHIO, William, “Television's Next Generation: Technology/Interface Culture/Flow”, in SPIGEL, Lynn, OLSSON, Jan (dir.), Television After TV. Essays on a Medium in Transition, Durham, London, Duke University Press, 2004, p. 163-182.

WINCKLER, Martin, Petit éloge des séries télé, Paris, Gallimard, 2012.

\section{NOTES}

1. Eco Umberto, «Innovation et répétition: entre esthétique moderne et postmoderne », Réseaux, n 68, 1994, p. 1-18.

2. In this sense, it would be a question of giving a central place to one of the seven principles identified by Henry Jenkins as the founders of transmedia storytelling, i.e. seriality. See his blog, Confessions of an Aca-fan: http://henryjenkins.org/blog/2010/06/ transmedia_education_the_7_pri.html, consulted on 7 July 2019.

3. Marta Boni, Romanzo Criminale. Transmedia and Beyond, Venise, Ca' Foscari Online Publishing, 2013, http://virgo.unive.it/ecf-workflow/upload_pdf/Innesti_2.pdf; Marta Boni (dir.), World Building. Transmedia, Fans, Industries, Amsterdam, Amsterdam University Press, 2017.

4. Yves Citton, Pour une écologie de l'attention, Paris, Seuil, coll. « La Couleur des idées », 2014.

5. Jean-Pierre Esquenazi, Les séries télévisées : l'avenir du cinéma?, Paris, Armand Colin, 2007 ; Martin Winckler, Petit éloge des séries télé, Paris, Gallimard, 2012 ; Vincent Colonna, L'art des séries télé, Paris, Payot, 2015.

6. Sylvaine Bataille et Sarah Hatchuel, «Préface. Les séries télévisées dans le monde : échanges, déplacements et transpositions »,TV/Series, $n^{\circ} 2$, 2012, put online on 1 November 2012 : http:// journals.openedition.org/tvseries/1351, consulted on 12 March 2018.

7. Séverine Barthes, «Panorama de la recherche universitaire sur les séries télévisées en France ", Premières Rencontres des Séries Télévisées, France, 2004 : http://hal.archives-ouvertes.fr/ hal-00470237, consulted on 7 July 2019.

8. Barbara Laborde, "Television Series: Inventory of Research in France", Series. International Journal of TV Serial Narratives, Volume III, n² 2, winter 2017: https://series.unibo.it/article/view/ 7631 , consulted on 7 July 2019. 
9. Ashley Rodriguez, "The End of Peak TV Must Finally, Mercifully Be Nigh", Quartz, 13 January 2018: https://qz.com/999827/the-end-of-peak-tv-must-finally-mercifully-be-nigh/, consulted on 7 July 2019.

10. William Uricchio, “Television's Next Generation: Technology/Interface Culture/Flow", in Television After TV. Essays on a Medium in Transition, ed. Lynn Spigel and Jan Olsson, Durham, London, Duke University Press, 2004, p. 163-182.

11. Stéphane Benassi, Séries et feuilletons T.V.: pour une typologie des fictions télévisuelles, Liège, Éditions du CEFAL, 2000 ; Esquenazi, op. cit.. On 28 February 2018, Claire Cornillon proposed a paper on semi-figurative seriality to the University of Le Havre Normandy in which the terms used by Jean-Pierre Esquenazi were used to describe very different, even opposing objects : https://www.youtube.com/watch?t=202s\&v=X3NT_4oYjDw\&app=desktop.

12. Milly Buonanno, Le formule del racconto televisivo. La sovversione del tempo nelle narrative seriali, Florence, Sansoni, 2002; Jason Mittell, Complex TV. The Poetics of Contemporary Storytelling, New York, NYU Press, 2015.

13. Albert Moran, Copycat Television: Globalisation, Program Formats and Cultural Identiy, Luton, Bedfordshire, UK, University of Luton Press, 1998; Jean Chalaby, The Format Age: Television's Entertainment Revolution, Cambridge, Polity, 2015; Guillaume Soulez et Kira Kitsopanidou (dir.), « Le levain des médias - Forme, format, média », MEI - Médiation et information, n 39, 2015.

14. Florent Favard, La promesse d'un dénouement. Énigmes, quêtes et voyages dans le temps dans les séries télévisées de science-fiction contemporaine, doctoral thesis, Université Bordeaux Montaigne, 2015 ; Florent Favard, Le récit dans les séries de Science-fiction de Star Trek à X-files, Paris, Armand Colin, 2018.

15. Luca Barra, "Master of None, Atlanta, and Audience Engagement in. Contemporary American TV Comedy”, $16: 9$ Filmtidsskrift, 19 November 2017 : http://www.16-9.dk/2017/11/master-ofnone/ (consulted on 7 July 2019); Luca Barra, «Les formes, durées et formats des comédies télévisuelles américaines. Distribution, engagement du public et instabilité des frontières de genre ", dans Marta Boni (dir.), Formes et plateformes de la télévision à l'ère du numérique, Rennes, Presses Universitaires de Rennes, 2019.

16. It should be pointed out that this serialising logic - inherited from the stand-up comedy format on which the series Master of None was created and produced by actor and comedian Aziz Ansari is based - does not necessarily continue afterwards, as is the case with many series which, as the seasons go by, see their narrative arcs become more serialised.

17. While "Quality TV" further defines a luxurious and "cinematic" mode of production used by American cable channels to attract cultivated niche audiences not accustomed to "standard television", "Complex TV" applies above all to the narrative and aesthetic characteristics of certain series, regardless of the channels that produce them, since a network series can fit perfectly into the paradigm conceptualised by Mittell.

18. Warren Buckland (dir.), Puzzle Films: Complex Storytelling in Contemporary World Cinema, Malden, Wiley-Blackwell, 2009.

19. David Bordwell, "What-if Movies: Forking Paths in the Drawing Room", Observations on film art (blog), 2014: http://www.davidbordwell.net/blog/2014/11/23/what-if-movies-forking-pathsin-the-drawing-room/, consulted on 7 July 2019; Steffen Hven, Cinema and Narrative Complexity. Embodying the Fabula, Amsterdam, Amsterdam University Press, 2017.

20. Marta Boni, « Mondes sériels et complexité », Écrans, Volume 2, n 4, 2015, p. 55-68.

21. Favard, 2015, p. 32-37.

22. Favard, 2015, p. 36.

23. Raphaël Baroni, La Tension narrative. Suspense, curiosité, surprise, Paris, Seuil, 2007.

24. Alain Boillat, Cinéma, machine à mondes : essai sur les films à univers multiples, Genève, Georg, 2014. 
25. Mireille Berton, «Flashback, trauma et répétition narrative dans les séries américaines contemporaines ", Télévision, n 7, 2016, p. 173-189.

26. Several authors have also noted the need to reconsider the conceptualisation of the television series fan who is sometimes described as a "seriesphile" (see Hervé Glevarec, La sériephilie. Sociologie d'un attachement culturel, Paris, Ellipses, 2012) and sometimes as a "telephile" (see John Caughie, "Telephilia and Distraction: Terms of Engagement", Journal of British Cinema and Television, vol. 3, No. 1, January 2008, pp. 5-18), or as a 'telecinephile' (see Daniela Cardini, 'Serial Contradictions: The Italian Debate on TV Series', Series. International Journal of TV Serial Narratives, Volume II, No. 1, Spring 2016, pp. 47-54: https://series.unibo.it/article/view/6163, consulted on 7 July 2019 ; and Daniela Cardini, «Il tele-cinefilo. Il nuovo spettatore della Grande Serialità televisiva ", Between. Rivista dell'Associazione di Teoria e Storia Comparata della Letteratura, Volume 4, $\mathrm{n}^{\circ} 8$, November 2014, p.1-30: http://ojs.unica.it/index.php/between/article/view/1361? fbclid=IwAR01riiC45RrKUXLIl4lT_Gv0YlPmPclEneLMrMEa1mbG8CmOkh_QkrQ9jY (consulted on 7 July 2019).

27. Veronica Innocenti and Guglielmo Pescatore, "Changing Series: Narratives Models and the Role of the Viewer in Contemporary Television Seriality", Between. Rivista dell'Associazione di Teoria e Storia Comparata della Letteratura, Volume 4, n 8, 2014, p. 1-15: http://ojs.unica.it/index.php/ between/article/view/4, consulted on 19 June 2019.

28. Anne Besson, Constellations. Des mondes fictionnels dans l'imaginaire contemporain, Paris, CNRS Édition, 2015 ; Anne Besson, « De l'ensemble à la totalité : l'effet de monde dans les littératures de l'imaginaire contemporaines ", Belphégor, $\quad n^{\circ} 14, \quad 2016:$ http://journals.openedition.org/ belphegor/650, consulted on 7 July 2019.

29. Anaïs Goudmand, "Les séries transmédiatiques. Des univers sans fins? ", Proteus, $\mathrm{n}^{\circ} 9$, p. 8-18, $2015:$ http://www.revue-proteus.com/articles/Proteus09-1.pdf, consulted on 7 July 2019 ; Henry Jenkins, La culture de la convergence : des médias au transmédia, Paris, Armand Colin, 2013 ; Richard Saint-Gelais, Fictions transfuges. La transfictionnalité et ses enjeux, Paris, Seuil, 2011 ; Stéphane Benassi, «Transfictions », MédiaMorphoses, Hors-Série, 2007, p. 158-162.

30. Raphaël Baroni and François Jost (dir.), "Repenser le récit avec les séries télévisées", Télévision, n 7, 2016 : https://www.cairn.info/revue-television-2016-1.htm, consulted on 19 June 2019; Anaïs Goudmand, "Narratologie du récit sériel. Présentation de quelques enjeux méthodologiques ", Proteus, $\mathrm{n}^{\circ}$ 6, 2013, p. 81-89: http://www.revue-proteus.com/ abstracts/06-10.html, consulted on 7 July 2019; Monica Michlin, «More, More, More. Contemporary American TV Series and the Attractions and Challenges of Serialization As Ongoing Narrative ", Mise au point, $\mathrm{n}^{\circ}$ 3, 2011: http://map.revues.org/927, consulted on 7 July 2019.

31. Robert C. Allen, (dir.), To Be Continued... Soap Operas Around the World, London/NewYork, Routledge, 1995; David Buxton, Les séries télévisées. Formes, idéologie et mode de production, Paris, L'Harmattan, 2010.

32. Marta Boni, "Working with Maps: Systems, Networks, Series", in A History of Cinema Without Names II. A Research Project, FilmForum/2015, ed. Diego Cavallotti, Federico Giordano, Leonardo Quaresima, Udine, Mimesis, 2017, p. 69-76.

33. Matthieu Letourneux, Fictions à la chaîne. Littératures sérielles et culture médiatique, Paris, Seuil, 2017; Matthieu Letourneux (dir.), «Sérialités », Belphégor, n 14, 2016 : http:// journals.openedition.org/belphegor/647, consulted on 7 July 2019.

34. Letourneux, 2016, p. 2.

35. Jean-Pierre Esquenazi, Éléments pour l'analyse des séries télévisées, Paris, L'Harmattan, 2017 ; Jean-Pierre Esquenazi, Sociologie des œuvres : de la production à l'interprétation, Paris, Armand Colin, 2007.

36. Letourneux, 2016, p. 2. 
37. Jane Feuer, "HBO and the Concept of Quality TV", in Quality TV: Contemporary American Television and Beyond, ed. Janet MacCabe and Kim Akass, London, I.B. Tauris, 2007, p. 145-157.

38. Valentina Re, "Beyond the Threshold. Paratext, Transcendence, and Time in the Contemporary Media Landscape", in The Politics of Ephemeral Digital Media: Permanence and Obsolescence in Paratexts, ed. Paolo Noto and Sara Pesce, New York, London, Routledge, 2016, p. 60-74.

39. Letourneux, 2016, p. 5.

40. Letourneux, 2016, p. 6.

41. Esquenazi, 2007 b, p. 87.

42. Edgar Morin, Introduction à la pensée complexe, Paris, Seuil, 2005 [nouv. éd.].

43. Marta Boni, 2015.

44. Yuri Lotman, Universe of the Mind: A Semiotic Theory of Culture, Bloomington, Indiana University Press, 1990, p. 131 (our translation).

45. http://www.shotlogger.org/, consulted on 7 July 2019.

46. See for example https://medieninitiative.wordpress.com/2017/02/16/deformative-criticismat-scms17/

47. http://labotele.com/, consulted on 7 July 2019.

48. Franco Moretti, Atlas of the European Novel, 1800-1900, London, Verso, 1999; Franco Moretti, "Planet Hollywood", New Left Review, n 9, May-June 2001: https://newleftreview.org/II/9/francomoretti-planet-hollywood, consulted on 7 July 2019; Franco Moretti, Graphs, Maps, Trees: Abstract Models for a Literary History, London, Verso, 2005.

49. See the website: "Narrative Ecosystems: Exploring Contemporary Serials Narratives as Complex Ecosystems": http://www.narrativecosystems.org/wp/ , consulted on 7 July 2019.

50. Marta Boni, «Des téléspectateurs géolocalisés », Sens Public, 15 December 2017 : http:// www.sens-public.org/article1283.html, consulted on 7 July 2019.

51. See also Abigail De Kosnik, "Piracy is the Future of Television", Convergence Culture Consortium, 2018, http://convergenceculture.org/research/c3-piracy_future_televisionfull.pdf, consulted on 7 July 2019.

\section{ABSTRACTS}

How to study the specificity of television series building evolving, shapeshifting, open, fragmented narratives? Questioning the use of the notion of complexity within and beyond narratology, this article proposes to read television series through an interdisciplinary perspective focused on spatialization. Indeed, beyond textual analysis and in the absence of primary sources on the production side (sources that more often than not prove inaccessible), the television series scholar is bound to explore the intermediate space between representation and reception - a complex space frequently navigated by users, as shown by the circular model of participatory culture (Jenkins, 2013).

Comment étudier les spécificités des séries télévisées qui forment des récits évolutifs, multiformes, ouverts, articulés en plusieurs fragments? Retraçant l'emploi de la notion de complexité avec et au-delà de la narratologie et présentant les défis que pose l'analyse de ces objets, la présente contribution propose de lire les séries télévisées à partir d'une approche interdisciplinaire centrée sur la spatialisation des séries. En effet, en complément de l'analyse 
textuelle et dans l'absence de sources primaires du côté de l'instance de production (lesquelles s'avèrent la plupart du temps inaccessibles), l'analyste des séries télévisées est amenéee à explorer cet espace intermédiaire qui se situe entre la représentation et la réception - un espace complexe et fréquemment investi par les usagers, comme l'a montré le modèle circulaire de la culture participative (Jenkins, 2013).

\section{INDEX}

Keywords: spatialization, complexity, participatory culture, narrative

Mots-clés: spatialisation, complexité, culture participative, récit

\section{AUTHORS}

\section{MIREILLE BERTON}

Mireille Berton is a senior lecturer at the Department of Film Studies of the University of Lausanne (Switzerland). Her research focuses on the relationship between cinema and sciences of "the mind", media technologies and the imaginary, and on the cultural history of spectatorship. She has published Le Corps nerveux des spectateurs. Cinéma et sciences du psychisme autour de 1900 (2015), coedited La Télévision du Téléphonoscope à YouTube. Pour une archéologie de l'audiovision (2009) and an issue on television series for Décadrages. Cinéma à travers champs (2016).

Mireille Berton est maître d'enseignement et de recherche à la Section d'Histoire et esthétique du cinéma de l'université de Lausanne. Ses travaux et enseignements portent sur les rapports entre cinéma et sciences du psychisme, sur l'histoire des imaginaires médiatiques, ainsi que sur les enjeux narratifs, culturels et sociaux des séries télévisées. Elle a publié Le Corps nerveux des spectateurs. Cinéma et sciences du psychisme autour de 1900 (2015), et a co-dirigé La Télévision du Téléphonoscope à YouTube. Pour une archéologie de l'audiovision (2009), ainsi qu'un numéro sur les séries télévisées de la revue Décadrages. Cinéma à travers champs (2016).

\section{MARTA BONI}

Marta Boni is an associate professor in Film and Television Studies at the University of Montreal, where she founded the Labo Télé. Her work centers on theoretical and pragmatic issues relating to narrative and semiotic complexity. She published Romanzo Criminale. Transmedia and Beyond (Ca' Foscari University Press, 2013); co-edited with Adrienne Boutang, Barbara Laborde et Lucie Mérijeau Networking Images. Approches interdisciplinaires des images en réseau (Presses de la Sorbonne Nouvelle, 2013) ; edited World-Building. Transmedia, Fans, Industries (Amsterdam University Press, 2017); and published several chapters and articles in scientific journals.

Marta Boni est professeure agrégée au Département d'histoire de l'art et d'études cinématographiques de l'Université de Montréal, où elle a fondé le Labo Télé. Elle travaille sur les problèmes théoriques et méthodologiques liés aux phénomènes de type sériel, dont elle explore la complexité narrative et l'entrelacement avec la réception. Elle a publié Romanzo Criminale. Transmedia and Beyond (Ca' Foscari, 2013) ; co-dirigé avec Adrienne Boutang, Barbara Laborde et Lucie Mérijeau Networking Images. Approches interdisciplinaires des images en réseau (Presses de la Sorbonne Nouvelle, 2013) et dirigé World Building. Transmedia, Fans, Industries (Amsterdam University Press, 2017), ainsi que plusieurs chapitres et articles sur ces thèmes. 